\section{Ewa Krzaklewska*}

Jagiellonian University

ORCID: 0000-0002-7662-3373

\section{Ewelina Ciaputa***}

Jagiellonian University

ORCID: 0000-0002-9102-1039
Justyna Struzik****

Jagiellonian University

ORCID: 0000-0003-3381-6180

\title{
WHY DOES IT HAPPEN IN PHYSICS? OPINIONS OF EUROPEAN PHYSICISTS ON GENDER INEQUALITY
}

\begin{abstract}
The article aims to describe and analyse the opinions of European physicists as to the reasons for the overrepresentation of men in the discipline, as well as to supply some reflections on the barriers encountered by female physicists in their careers. The article is based on qualitative data -83 in-depth interviews with female and male physicists - collected in 2016 and 2017 under the framework of the project "Gender Equality Network in European Research Area" (GENERA). The main reasons voiced by interviewees for the gender imbalance in physics are to be found 'outside' the scientific institutions themselves, namely the early processes of the socialisation of girls and boys, together with existing gender stereotypes. Other reasons are related to recent developments in academia linked to work organization and structural conditions - precariousness, competitiveness, and the demand for mobility, but also to a masculinised working culture resulting in gender bias, as well as microaggressions and discrimination. In relation to recent studies showing that awareness of gender (in) equalities remains of crucial importance for structural/institutional change, the article reflects on the potential implications of the perception by physicists of the determinants of gender inequality for the implementation of gender equality policy in research organisations.
\end{abstract}

Keywords: gender (in)equality awareness; gender equality measures and plans; physics; research-performing organizations; gender equality policy

* Corresponding author: Ewa Krzaklewska, Uniwersytet Jagielloński, Instytut Socjologii, ul. Grodzka 52, 31-044 Kraków; e-mail: ewa.krzaklewska@uj.edu.pl.

** Corresponding author: Paulina Sekuła, Uniwersytet Jagielloński, Instytut Socjologii, ul. Grodzka 52, 31-044 Kraków; e-mail: paulina.sekula@uj.edu.pl.

*** Corresponding author: Ewelina Ciaputa, Uniwersytet Jagielloński, Instytut Socjologii, ul. Grodzka 52, 31-044 Kraków; e-mail: ewelina.ciaputa@uj.du.pl.

**** Corresponding author: Justyna Struzik, Uniwersytet Jagielloński, Instytut Socjologii, ul. Grodzka 52, 31-044 Kraków; e-mail: justyna.struzik@uj.edu.pl. 


\section{INTRODUCTION}

While measures and solutions such as Gender Equality Plans (GEPs) have become more widespread in the EU (European Commission 2019) as part of a drive to tackle gender inequalities within scientific institutions, one of the toughest barriers towards their implementation appears to be internal resistance within academic institutions themselves (Lane 2007; Lee et al. 2010; EIGE 2016; Bleijenbergh 2018). It has been argued that awareness of gender inequalities is a crucial determinant of the successful implementation of GEPs or other related measures (Acker 2006; Lane 2007; European Commission 2009; Lee et al. 2010; van den Brick 2015; EIGE 2016). In fact, within the gender equality policies implemented in research performing organizations, training sessions and workshops on gender inequalities are a basic tool for tackling the problem of gender bias and discrimination (Lee et al. 2010).

We take the discipline of physics as an example, where the numerical underrepresentation of women is significant. Consolidated data concerning all fields of science demonstrate that in most European countries the proportions of women among researchers in natural sciences are considerably smaller than in all fields combined, and in comparison to other fields (European Commission 2019; Eurostat 2019). For example, the proportions of female researchers in higher education institutions in European countries varied in 2015 from $21 \%$ to $54 \%$ in the case of the natural sciences, and from $37 \%$ to $70 \%$ in medical and health sciences (European Commission 2019). More specifically, according to data from the Elsevier report on gender in the global research landscape (2017), women comprise around a quarter of the researchers in physics and astronomy within the EU-28 nations.

Similarly, the so-called 'leaky pipeline' phenomenon - a universal pattern of women dropping out of research and academic careers at a faster rate than men - is more severe in the fields of science, technology, engineering and mathematics (STEM) than in all fields of research considered together. In 2016 , women were $46 \%$ of grade $C$ staff, $40 \%$ among grade B staff and $24 \%$ of grade A staff in all academic fields in the EU. Simultaneously, in STEM fields women were $35 \%$ of grade C staff, $28 \%$ of grade B staff and $15 \%$ of grade A staff (European Commission 2019). The data collected within the consortium of the GENERA (Gender Equality Network in European Research Area) project in 2016 and 2017 demonstrates that gender gaps in physics might also be wider, as the share of female scientists employed in physics departments varied between $10 \%$ and $33 \%$ and they represented from $0 \%$ to $20 \%$ of grade A staff. ${ }^{1}$

Drawing on the qualitative data ( 83 in-depth interviews with physicists) collected in 2016 and 2017 under the framework of the GENERA project, ${ }^{2}$ we describe and analyse opinions concerning reasons for the overrepresentation of men in the discipline and reflections on existing barriers encountered by female physicists in their careers. Based on these findings,

\footnotetext{
1 Only in one organization did women constitute $41 \%$ of scientists. For the list of research organizations participating in the GENERA project, see: https://genera-project.com. The data discussed here were circulated among the consortium members and have not been made public.

2 GENERA is a Horizon 2020 project funded by the European Union under GERI-4-2014 01 September 2015 31 August 2018 grant agreement 665637.
} 
Why does it happen in physics? Opinions of European physicists on gender inequality

we reflect on the potential implications of gender inequality awareness within the field of physics for the implementation of institutional change in research performing organizations (research centres, institutes, and higher education institutions).

\section{GENDER AWARENESS}

\section{AS A DETERMINANT OF INSTITUTIONAL CHANGE}

Institutional change towards gender equality in research and higher education is often accompanied by various barriers, including resistance at both the individual and institutional levels (Lane 2007; Lee et al. 2010; van den Brink 2015; Moss-Racusin et al. 2015; EIGE 2016; Bleijenbergh 2018). Perceived from different perspectives, both as discursive practices (Powell et al. 2018) and "as a characteristic of a system where gendered organizations tend to move back towards an equilibrium when confronted with change" (Bleijenbergh 2018: 132), resistance manifests itself in various forms. One of them is denying the need for change by arguing that gender inequality is (no longer) a problem, questioning the methodology, epistemology and results of feminist research documenting the scope and forms of gender inequalities, and explaining differences in careers by referring to the different natures of men and women (Lee et al. 2010; Lombardo and Mergaert 2013; van den Brink 2015; Bleijenbergh 2018; Powell et al. 2018; Verge et al. 2018). Another strategy is to trivialize gender equality by arguing that there are more pressing priorities, claiming that change will come naturally without the need for intervention, and by considering imbalances in an academic career as being mainly a "women's problem" (Lombardo and Mergaert 2013; Powell et al. 2018; Verge et al. 2018). Finally, the refusal to take responsibility for dealing with gender equality issues manifests itself in the denial of the relevance of the gender perspective for the natural sciences, emphasizing the complexity of the issue and claiming that gender-equality measures cannot be imposed (Lombardo and Mergaert 2013; Verge et al. 2018).

Gender awareness is widely perceived as one of the key links between gender inequalities and action for change (Acker 2006; Lane 2007; European Commission 2009; Lee et al. 2010; van den Brick 2015; EIGE 2016). In this context, Lee et al. (2010) argue that to 'make the case' for gender equality and diversity policies, at least three steps of enhancing acquisition of gender knowledge and raising gender awareness are necessary. First, "people have to be persuaded that there is indeed inequality" (Lee et al. 2010: 94). The point is to encourage open and non-trivial discussions about gender, mainly by providing "hard" (statistical) data on retention, attrition and career inequalities to demonstrate the extent of gender imbalances at all levels of the organization. Second, "people have to be persuaded that there are good reasons for seeking to change the situation revealed by the data" (Lee et al. 2010: 95), as gender imbalances in retention and progression are not exclusively the result of individual choices or gender differences in ability and inclination. Here the argumentation for social justice and the full utilisation of female talent is evoked. Third, "people need to be persuaded of the case for specific gender equality and diversity policies" (Lee et al. 2010: 95). This demands the diffusion of knowledge as to how individual staff members, or the organization as a whole, contribute to enhancing or inhibiting gender equality, as well as highlighting the 
benefits stemming from specific policy measures, which often extend beyond gender change. By means of an example, one might mention the introduction of flexible work arrangements, which provide both a better work-life balance for employees as well as a healthier and more efficient workforce for employers (Lee et al. 2010: 93). ${ }^{3}$ As far as the stakeholders inside the institution are concerned, it is additionally argued that it is crucial to win over those who have never been exposed to issues related to gender or gender issues in science and technology (McGregor and Bazi 2007: 24).

Therefore, gender awareness training sessions and workshops are widely acknowledged and used as a tool for overcoming resistance to gender equality initiatives in the workplace, including research and higher education providers (Lee et al. 2010; LERU 2018), such as physics departments (Sekuła and Pustułka 2016). Such training sessions are one of the most common tools within Gender Equality Plans in research performing and funding organisations (Reild et al. 2019). However, the evidence for the effectiveness of gender awareness and diversity training is mixed. Some studies record a link between educating participants about the existence of bias and subsequent reductions in biased attitudes and behaviours (Shields et al. 2011; Carnes et al. 2012), which may translate into increased recruitment levels of female faculty in science departments (Devine et al. 2017). Other studies reveal the limitations of the impact of gender awareness interventions on reducing resistance and fostering institutional change. Moss-Racusin et al. (2015) and van den Brink (2015) demonstrate that presenting the evidence of gender bias based on both quantitative and qualitative research may be met with denial, trivialization of the evidence, or even attempts to justify the existence of gender bias when this evidence is perceived as undermining the fairness of the existing academic system.

The problem of the views of scientists in terms of the determinants of gender inequalities in research and academia has been understudied, but a few analyses suggest the existence of competing narratives and their gendered nature. When confronted with the problem of gender segregation in scientific disciplines, scientists themselves often provide different explanations. These narratives include natural gender differences, which cause women to be better-suited or more interested in some disciplines than in others, women being actively discouraged from entering certain disciplines throughout the educational process, a lack of female role models, the result of a historical tradition of gender segregation in a given discipline, and perceptions of the impact of a career in a discipline on family choices (Pettersson 2011; Ecklund et al. 2012; Hughes et al. 2017). Both men and women provide differentiated reasons for the low proportion of female faculty in selected fields. However, while male scientists typically refer to biological differences, female scientists, including physicists, are keener to emphasize the role of social factors, including gender stereotypes and expectations towards the careers of men and women, as well as gender discrimination and gender bias in the workplace (Ivie et al. 2002;

\footnotetext{
However, as long as flexibility is considered a typically 'female' way of organising work time, flexible working may promote a traditional division of labour which ultimately hinders rather than supports gender equality (European Commission 2010). Furthermore, recent studies and debates on precarious and insecure conditions of work in academia have challenged the positive evaluation of flexible work arrangements. It has been demonstrated that such solutions may blur boundaries between work and leisure/free time and provoke a feeling that work is never done (Wilton and Ross 2017). The negative aspects of flexible work are also reinforced when researchers experience employment insecurity.
} 
Hirshfield 2010; Ecklund et al. 2012; Barthelemy et al. 2016; Hughes et al. 2017). Regardless of the gender differences demonstrated in explaining the gender gap in research organisations, as well as the awareness of continued gender discrimination in the workplace, some studies conclude that scientists perceive gender inequality as predominantly stemming from factors over which research organizations or companies have no control. These include biological gender differences and perceived female disinterest in a given field, deep-seated gender stereotypes and norms, as well as an educational system which discourages girls from choosing a career in selected disciplines (Kelan 2007; Carvahlo and de Lourdes Machado-Taylor 2017).

\section{STUDY METHODOLOGY}

The article is based on interviews with 83 physicists working in 12 research institutes and universities in eight European countries: Germany (18), The Netherlands (2), Italy (12), Spain (9), Switzerland (5), Romania (9), France (6), and Poland (22). The interviews were conducted in 2016 and 2017 within the framework of the GENERA project by partner institutions in those countries. While the overall research endeavour within this project had broader aims of exploring the career paths of physicists, identifying existing gender inequalities in physics, and verifying strategies to overcome barriers that hinder the development of female physicists' careers, this article concentrates on selected findings in relation to physicists' opinions on inequalities in the field. The material used here relates to the interview section, in which respondents were asked about the possible reasons for male overrepresentation in physics and the potential barriers encountered by female scientists working as physicists. While this is a qualitative study of an explorative character, the picture provided makes no claim to analyse the actual situation of female physicists, but the physicists' subjective opinions on gender inequality in physics.

Sixty-five interviews were conducted with physicists, both female (43 interviews) and male (22 interviews), at different stages in their careers and from various sub-disciplines of physics. The semi-standardised interviews were carried out in order to reconstruct the subjective theories of physicists about their workaday life and experiences (Flick 2006: 155). In relation to each subtheme within the study (career path, mobility, reconciliation of work and private life, work environment, networking, mentoring, experienced discrimination, opinions about gender policy), an open question was posed to the interviewee before follow-up questions were asked. Then, 18 expert interviews were conducted with organisational leaders, including rectors, deans, directors, project leaders, and HR experts, all coming from the same 12 institutions. The expert interviews in our study were focused on the expert and contextual knowledge of leaders concerning the situation of female scientists in physics, implementation of gender equality policies, and their evaluation. The interviews were conducted in the relevant local language by partner institutions on the basis of a prepared research manual and interview guide. The structured notes, including citations, were prepared from each interview - these were coded using open and theory-driven codes (for more information on the method and analysis employed, see Sekuła et al. 2018).

It is important to stress the limitations of our research, even if the sample in our study is quite large. As the research was conducted under the auspices of a European project, this 
allowed us to reach more countries, but this in turn led to a number of limitations, such as different sample sizes in institutions, potential issues with translation, and cultural differences in understanding the concepts and notions in questions by respondents, and the variable quality of materials received from the different institutions. Another valid matter is the possibility to draw conclusions in relation to countries, as the number of female researchers is very low and, due to the possibility of participants being identified, the GENERA project decided that the country of origin of the study participants would not be revealed. Within those limitations, this study provides a generalized picture of the opinions of members of the European physics community, without drawing conclusions in relation to their country of work/origin. While country variations in terms of occupational standards, academic cultures and the strength of certain gender stereotypes are of crucial importance, we believe there are general trends within the community which we will illustrate in this article, without forgetting the unpresented variations.

\section{GENDER INEQUALITY IN PHYSICS:} AN ISSUE THAT NEEDS TO BE DEALT WITH?

In our study we asked physicists about the causes of male overrepresentation in physics, as well as the barriers that female scientists may face in their careers as physicists. The claim that men are "in the majority" did not come as a surprise to our study participants, with most of them agreeing with this notion based on statistics or in relation to their own experiences. None of the respondents questioned this fact, while a few underlined the exceptional situation of their country, institution or research group, or specific branches of physics such as biophysics.

It is important to stress that the participants not only referred to the quantitative overrepresentation of men in the field and governing or decision-making bodies, but also to the matter of symbolic domination - the physicists underlined the existing symbolic figure of a scientist being a man, and the masculine culture of physics within which some women feel isolated or unwelcome (the term "boys club" was used by one of the interviewees).

While study participants are well aware of the quantitative or symbolic domination of men, a few found it difficult to disentangle the actual causes of this situation. A declared lack of knowledge about the causes of gender imbalance in physics does not necessarily pair with the assumption that the topic is not an important one - in some cases, participants sounded rather hopeless that the issue still pervades the scientific world:

I don't have a clue about why it's like that. I have two daughters, they are very brilliant in mathematics or physics, they are really interested in science. I don't know where the break comes from, why so few women go for physics. It was already like this in my time, when I did my studies, we didn't have more than 2 or 3 women at PhD level. I'm still asking myself why, and why it didn't change. $35 \_\mathrm{M}^{4}$

4 Respondents are identified in the text by a code which indicates the number of the interview (01-83), interviewee's gender (F, M) and, if applicable, leadership position (L). Specifying countries in which the respondents were employed as well as their academic positions was omitted in the interest of anonymity. 
At the other end of the spectrum, there are those who have gone through much reflection concerning their own trajectories in physics (particularly females) and the situation of female researchers, and have even attempted to undertake actions (individual or systemic) in order to tackle the witnessed gender inequality or discrimination. Their in-depth concerns around gender inequalities, as well as the reflections of some of respondents in leadership positions, illustrates the important switch within the discussion around the gender imbalance in physics from "the problem of women with physics" to the "problem of physics with women" (Götschel 2011) or rather - as we would call it - "the problem of physics with gender inequality". One can witness an intensification of the debate within the academic community over low female representation or even their absence among the body of physicists, ${ }^{5}$ and it becomes a responsibility of institutions to reflect upon their functioning in relation to the attrition and retention of women scientists and to tackling inequalities. Particularly, activity is seen in relation to creation of GEPs: the latest EU report She Figures 2018 (European Commission 2019) indicates that in 56\% of EU Research Performing Organizations such a tool exists.

Beyond declarations of concern, the voice that gender inequality is not of immediate worry for physics as a field, or that this is just how it is, is also represented. One attitude, based on a comparison to other disciplines where a reverse gender imbalance exists, juxtaposes physics with fields that face the opposite situation and "justifies" the dominance as a phenomenon. Such statements are related to the passive approach to the problem.

[In physics men dominate when it comes to numbers. What are the causes of this?] I would turn around this question, does it have to be equal? For example, the situation where you have dominance of women in sociology, and then the dominance of men in physics, should this bother us? 72_M

It is a general problem that concerns all fields, not only physics. 48 F

The second argument relates to the existence of neutral, objectified evaluation procedures within science that constitute a barrier to potential bias and discrimination. The respondents, more often men, stress the ultimate importance of competence, knowledge, achievements and excellence on career development and advancement, with gender not having an impact on evaluation procedures. A belief in the fairness of the system is the basis for undermining any interventions within it (cf. Moss-Racusin et al. 2015).

In the physics I'm doing, high energy physics, it's really competence which counts, not even character. Of course you can have competition, but in a big collaboration it's looked upon very badly if you try to behave differently. The fight is only on scientific topics. 35_M

The third type of argumentation relates to the assumption that the gender imbalance in physics is connected to the notion that women simply do not want to be physicists. The position assumes that each person makes a free choice on their profession, according to one's predispositions or interests, and that female students simply choose other fields. Consequently, the simple fact of male students being in the majority is causing the imbalance within staff.

5 The GENERA project may be such a manifestation. This problem is discussed as well at physics conferences, usually in the form of panels or debates dealing with gender inequality within the field. 
This position may also relate to the notion of the gendered nature of competences and predispositions.

[Gender imbalance] stems from the fact that $[\ldots]$ there are different predispositions to some activities, there are more preschool female teachers and more female nurses. [...] If a woman feels that she wants to be a physicist there is no problem to be one. [...] this comes from the specificity of the profession. This exists all over the world and I am not sure if you can artificially change it, as it is deep in a person what they want to do in life. I just think fewer women want to be in this profession. 69_M

\section{IT DOES NOT HAPPEN IN PHYSICS - "EXTERNALIZING" THE DETERMINANTS OF GENDER INEQUALITY}

The most commonly mentioned reasons the interviewees give for the male surplus in physics are typically located outside their institutions. A large share of the interviewed physicists claim that cultural and historical context and cultural norms and values are of crucial importance, and thus consequently appear difficult to influence. First of all, the respondents link gender imbalance to the processes of the socialization and reproduction of gender stereotypes in youth, primarily the perception of typically male and female talents and predispositions towards scientific work. Girls in their early years are "informed" that science is not for them, and that boys are those who have "natural" talent for mathematics and "innate" technical skills. As our participants indicate, these processes are mostly perpetuated through educational systems (schools) and family, and they result in girls' low self-esteem in relation to mathematics, potentially and in practice, impacting their educational choices. Sometimes those cultural norms are so strong that they are treated as an objective difference; nevertheless, most of the interviewees underline the significance of children's socialization, learning and internalizing of stereotypes. Importantly, few participants realise that their own institutional practices can perpetuate those stereotypes - they mostly see their institutions, or even science as such, as "immune" to the cultural context and not reproducing gender stereotypes.

The problem comes from an idea that is implemented in children's brains very early on. Science is a boy's thing, not a girl's thing. It's terribly wrong, but it's a very common idea. 38_F_L

As well, the cultural expectations towards a women's role within the family are seen as being of critical importance, especially when they are already pursuing a scientific career. Respondents underline constraints resulting from social expectations towards female engagement in family life, with their professional career being perceived as of secondary importance. These social expectations have multiple serious implications for career decisions, e.g. negotiations with a male partner often result in the prioritisation of his career over hers. They also have an impact on the reconciliation of work and family, since while having a family can also affect a man's career, it is women who face social expectations which are linked to the fulfilment of the mother role and are hard to change. 
Why does it happen in physics? Opinions of European physicists on gender inequality

Physics loses its women after the PhD. Many female scientists decide to leave science at this point of their career. The women rather concentrate on the career of the (male) partner and/or become mothers. 19_M_L

The physicists also highlighted that the internalization of existing stereotypes, both of women's lower capacities to pursue a scientific career and those concerning their primary role as a mother, may result in low self-esteem and doubts about one's own genuine capacity to pursue a career in physics. This was also witnessed in our study, as women more often voiced doubts about their talents and predispositions - this phenomenon is known as the impostor syndrome, and it was known as well to some of the female participants who reflexively relate to it (Ivie, White and Chu 2016).

I actually think it mostly has to do with how we all have prejudices about what men and women should do and how they should lead their lives, who should be responsible for family. I think it's both that men have prejudices, but women also hold themselves back and decide not to follow a career in natural sciences. 16_F_L

And while gender norms towards family roles are seen as impossible to change in the short run, respondents nevertheless indicated that institutional solutions can and do help in the management of family duties in the context of work as well as reconciliation of family and professional roles.

Finally, while most participants had opinions about the impact of the socio-cultural context on the situation, some pinpointed objective differences between genders, their preferences or predispositions - they mention abstract or logical thinking as being easier for men, as well as levels of aggression or sociality, without necessarily claiming that these differences are innate. Interestingly, even if they sometimes admitted that there were some differences, they could not be sure that they would have an impact on a career in physics.

\section{THE GROWING IMPORTANCE OF STRUCTURAL CONDITIONS - CONTEMPORARY SCIENTIFIC INSTITUTIONS ARE PERCEIVED AS UNWELCOMING TOWARDS FEMALE SCIENTISTS}

The second block of reasons for gender imbalance is related to the functioning of the research institutions, or in general research or the academic "world". These arguments included reflection on the working culture and work conditions in the field that could potentially deter women from entering it. The narrative about "sacrifice to science" is seen in the interviews of both women and men, who underline the strenuous, often lonely, constant, 24-hour intellectual work. This androcentric vision of a scientist fully dedicated to science does not allow for engagements other than scientific work - such as a family - and thus only those women who put their work first, underplaying other activities, have the chance to succeed.

It works like that, that a woman is really ambitious and can manage life in a way that her work comes first. 66_F 
At the same time, the recent developments in the field (or in academia in general) linked to work organization and structural conditions are becoming increasingly important. Three traits of the contemporary physicist's career were underlined as potentially causing more challenges to women, especially those of the younger generation of physicists: precariousness, competitiveness, and the demand for mobility. These aspects of a scientific career are also challenging to the image of a scientist present in the above-described narrative as one who is fully absorbed by scientific concerns - today, career management has become an additional duty. With these new demands, which are faced and negatively evaluated by both men and women alike, it is believed that women are less willing to work under these new conditions and that they constitute a serious barrier. As entering a career in academia is often linked to extending a period of precariousness and working on short term, grant-based contracts, the unstable work conditions may deter women who would like to establish a family or already have one. In the new model of a career, most achievements should be attained in the postdoc period (after completing one's $\mathrm{PhD}$ ) - the expectation is for a rapid advancement up to the level of the assembly of an independent research team. The period of family formation coincides with a time of unstable employment (usually, multiple post-docs with temporary contracts) as well as high productivity demands. The importance of the post-PhD phase for retaining women in science is stressed by many participants:

Long periods of precariousness That's why women choose university paths that lead to lower paying jobs, but stable and with less mobility (one of my colleagues has chosen to be a teacher). 47_M

We, as women, have been taught we have to take care, to be cautious about the future. Men are more taught to be adventurous, to take risks to succeed. I think it's reflected in the career path: men are less stressed to have several temporary jobs, while we concentrate on security. 37_F

The post-doc positions are often linked with a demand to relocate to a new country or even multiple countries - in a situation when a partner/husband does not want to migrate, this becomes practically impossible to realize. Also, intensive short-term mobility is difficult or often impossible for women who have children or who are caregivers in a more general sense.

You have to consider that in the chosen academic career you will be asked to travel a lot. To go to conferences, to workshops, to be on committees, and this is already something that normally a man can do without issues for all his life. While a woman, for a woman, for a few years this can be an issue.21_F_L

Finally, competitiveness - as a trait of physics - was mentioned as potentially deterring women from participation in the field. In fact, many female physicists in our study stressed the aspect of competition as being something they disliked about their work. On the other hand, there were critical voices which stressed that competitiveness is not unique to physics and that it affects both men and women.

[...] apart from cooperation there must be competition and [...] not a power struggle, but a fight for influence, to which men are believed to be foreordained and which is more [...] attractive for men than for women - maybe this is the reason and it shows more strongly in physics. 59_M_L

But I think physics in general is exhausting. Also for men. This constant competition. 07_F 
Within this line of argumentation, the contemporary condition of science is highlighted as a cause of gender inequalities, one which constitutes most of the barriers in women's careers or even prevents them from starting it following the completion of a $\mathrm{PhD}$. The institutional demands towards scientists, which in turn impact on working conditions, create an unwelcoming climate for women in physics. From this perspective, the decision to leave the scientific world may appear both rational and correct. Interestingly, working in industry was pinpointed as an option where the reconciliation of private, family and work life was easier (and where financial conditions were better). Concerning policy implications, scientists rarely indicated measures which would improve the situation of women in such conditions. Some solutions were only mentioned in relation to mobility, such as dedicated research funds for women or parents of both genders.

\section{IDENTIFYING BARRIERS WITHIN RESEARCH ORGANIZATIONS - THE EXPERIENCE OF BEING IN A MALE CLUB}

The third stock of arguments in relation to potential and actual barriers to women's careers in physics relates to the organizational environment. These are most often mentioned by women scientists and, more often than the previous statements, relate to the actual experiences of our female study participants.

The numerical predominance of men in research and higher education organisations has important consequences for the work environment and female well-being at work. Women who enter the field have to face the fact that they will be among the few of their gender to do so, a fact which may prove uncomfortable - "you ask yourself if you are in the right place", or cause fear or discouragement. As our study shows, the masculine model of a scientist is reproduced in different ways, from the androcentric model of work, to the organization of space, to ways of joking and communicating. Some male physicists are aware that the way they behave may be a cause of unconscious discrimination, as the style of communicating between men or the symbols they use may be obscure to females. Others are more critical and underlined misogyny and a lack of respect on the part of male colleagues towards female researchers. A lack of understanding of the different challenges that women may face in their career was also noted, such as those linked to parenthood. This may have consequences for institutional change, given the fact that most governing bodies are mainly comprised of men.

I've always had the impression the male club had this feeling of: we do understand [ourselves] better among us boys. 42_M

The community in physics consists mostly of men and they are missing the female perspective and don't understand the different needs and challenges from/for women in their career. 21_F_L

I have never come across conscious discrimination, but unconscious discrimination might take place, something which comes from habit and from the fact that physics has been dominated by men for a long time, and the fact alone that women constitute $10 \%$ in physics and men $90 \%$, this alone creates unbalance, because the man's world can be a bit different, it's based on slightly different rules [...], codes. 54_M_L 
The female researchers in our study often talked about the consequences of being in a male-dominated environment. The first group of consequences relates to various forms of discrimination. While overt discrimination appeared in the narratives, they are not mentioned frequently (e.g. lack of access to resources or cases of harassment). Instead, far more common are experiences of microaggressions, understood as "brief and commonplace daily verbal, behavioural or environmental indignities, whether intentional or unintentional, which communicate hostile, derogatory, or negative slights, invalidations, and insults to an individual or group because of their marginalized status in society" (Sue 2010: 5). A number of forms of microaggression have been identified, including: 'sexual objectification', 'second-class citizenship', 'use of sexist language', 'assumption of inferiority', 'restrictive gender roles', 'invisibility', and 'sexist jokes' as well as 'denial of the reality of sexism' (Sue 2010; see also Barthelemy et. al. 2016). For example, the invisibility of women in the workplace manifests itself in being ignored, overlooked, or not being asked to attend conferences or meetings, which in the opinions of the participants happens to them purely because of their gender and because "male colleagues [...] have a low estimation of female colleagues" (42_M) and makes them feel that they "don't belong to the community" (06_F):

So how often did we go to a fair or to, to, what is the word, the supplier. And then we were with two people. And then a man comes over and we say 'Yes, hello, we are blah and blah' and this guy, this guy, he only greets the man and I don't matter at all. Just straight up ignored, from beginning to end. Completely. Despite the fact that my colleagues sometimes said 'Yes, she is well versed, maybe she can say something about it' or something, they always went back to the other man [...]. 07_F

The second group of consequences is linked to the notion of gender bias, which is understood as "prejudiced actions or thoughts based on the gender-based perception that women are not equal to men in rights and dignity" (EIGE n.d.). It was noticed by the interviewees that women in physics need to "prove double" to receive similar evaluation - voices appeared indicating that for a woman physicist to achieve success, she must be much better than her male colleagues.

I say it loudly, and definitely in physics, at least in our institution, but I think all over the country, a woman needs to know much more than her male colleague to get a certain position or work. This is really true, I can say it from my experience. 70_F

As a woman in physics, you have to be really, really good to get the same status as a man. 29_M

An additional important consequence related to gender roles and relations is the delegation of low prestige (and time-consuming) tasks to women, such as taking notes during meetings or administrative tasks. Women are also often seen as teachers, and their engagement in teaching may lead to a lack of time to do research work.

And this is the barrier that me, but also my female colleagues, we were delegated to different tasks, like assisting, and the male colleagues were progressing. And then I was burdened with all the small things to do, so my time at work was full and I didn't have time to sit and reflect on some physics theories. Even if you notice it, it is difficult to liberate yourself. 65_F 
Concluding this section, these arguments relating the actual situation of women in their organizational environment were strongly rooted in the actual experiences of women scientists, as well as in the experiences of female colleagues or mentees. The mentioned experiences of discrimination, unequal treatment, and microaggression supply the basis to demand institutional solutions to inequality. Even so, the embeddedness of the organizational conditions in the wider context of functioning of academia or socio-cultural environments constitutes a barrier to such change, one which the interviewed physicists were aware of. However, this was perceived as being hard to influence, as well as being embedded in the unwritten rules of ways of doing things (as illustrated by the phrase quoted above: it is "difficult to liberate yourself"). Nevertheless, seeing the role of organizational arrangements as being of critical importance in assuring equality constitutes a good foundation for the design of policy measures in relation to prevention, as well as recognising and reporting inequality.

\section{CONCLUSIONS}

While recent research and practice indicate that gender awareness-raising tools and measures are of crucial importance for institutional change towards gender equality in research performing organizations, as our study shows this may have certain limitations. The opinions and attitudes towards reasons for gender imbalance and women's barriers for advancement in physics presented in this article show that physicists locate them predominantly 'outside' of their organisation. Physicists point to external factors such as gender stereotypes and norms linked to an educational system which discourages girls from choosing careers in STEM fields, resulting in disinterest on their part in the given field. These are compounded by deep-seated gender stereotypes and norms concerning family and work that impact on their actual careers. Some respondents also mentioned "objective" differences in predispositions or preferences between women and men. Another two sets of conditions which in the opinion of participants influenced the careers of women are related to institutional factors. First, they are linked to typical work conditions offered to scientists by research organisations. These are characterized by high demands, particularly in relation to productivity, management of one's own work and mobility, as well as competitiveness. All these factors are compounded by a lack of stable job positions. Second, the masculinized organisational culture creates a chilly climate, one which leads to various forms of unequal treatment experienced by women in their workaday lives. While these may also occur in a non-masculinised environment, other research indicates they are more common when the percentage of men is below 15\% (Kanter 1993).

The abovementioned results may have potential implications for policy change within the research field. As the "responsibility" for gender imbalance is relegated by the interviewed physicists to the cultural context and early processes of socialization which are located outside the academic world, interventions within or by one's institution may be seen as having no potential for success. Similarly, a share of respondents indicated in the study that the barriers to women are not to be found within their institution. This statement matches the 
assurance of the fairness of the represented institution (or science as such), the non-existence of discrimination, and the presence of adequate laws and regulations which prohibit this from happening. Such a position suggests that institutional interventions, such as implementing measures against gender bias or preventing discrimination, may be futile as they need to be implemented earlier, at the school level, or embrace society as a whole, which would be beyond the remit of scientists. Only a few study participants actually suggested measures related to those socio-cultural influences, mostly in relation to interventions in early education or providing female role models - it remains unclear whose responsibility it would be to undertake such actions, with physics or academia being only slightly interested in such interventions (e.g. in relation to recruitment or talent-hunting). Similarly, as transformations of work requirements in research organisations are seen as external and impossible to change as an institution, organization-level solutions are rarely seen as being possible to implement in order to support female scientists (even if it was underlined that women would be more impacted by those changes).

Organizational change is seen as needed mostly by those who have had experience of unequal treatment themselves (or among colleagues or mentees). And while the belief that inequality is embedded in 'ways of doing' within an institution may constitute the basis for designing some adequate policy measures, the difficulty of influencing organizational culture is well-discerned by our respondents. Even when male physicists are also self-aware of the chilly climate women encounter, this situation is still described as the status quo, one which is hard to change.

Ultimately, while we are witnessing a growing awareness of the gender imbalance in physics - both in relation to knowledge of the existence of inequality as well as its determinants, our data suggest that this awareness may not necessarily translate into support for the implementation of measures supporting female careers. As a recent ACT study indicates, the most important barrier to implementation of gender equality policies is, beyond a lack of resources, a lack of commitment from both employees and management (Reild et al. 2019). Therefore, even if the problems and potential challenges are explicated and articulated, and by male researchers as well, few measures are believed to be potentially effective in achieving gender equality. Nonetheless, a more reflexive attitude, often resulting from the actual experience of unequal treatment or microaggression, becomes a stronger basis for such support. Giving a voice to such personal experiences within the community could potentially be a driver for change.

\section{REFERENCES}

Acker, Joan. 2006. Inequality Regimes Gender, Class, and Race in Organizations, "Gender and Society", 20, 4: 441-464.

Barthelemy, Ramón, Melinda McCormick and Charles Henderson. 2016. Gender Discrimination in Physics and Astronomy: Graduate Student Experiences of Sexism and Gender Microaggressions, "Physical Review Physics Education Research", 12, 2: 1-14. 
Why does it happen in physics? Opinions of European physicists on gender inequality

Bleijenbergh, Inge. 2018. Transformational Change Towards Gender Equality: An Autobiographical Reflection on Resistance During Participatory Action Research, "Organization", 25, 1: 131-138.

van den Brink, Marieke. 2015. The Politics of Knowledge: The Responses to Feminist Research from Academic Leaders, "Equality, Diversity and Inclusion: An International Journal", 34, 6: 483-495.

Carnes, Molly, Patricia Devine, Carol Isaac, Linda Baier Manwell, Cecilia Ford, Angela ByarsWinston, Eve Fine, David Burke and Jennifer Sheridan. 2012. Promoting Institutional Change Through Bias Literacy, "Journal of Diversity in Higher Education", 5, 2: 63-77.

Carvalho, Teresa and Maria de Lourdes Machado-Taylor. 2017. The Exceptionalism of Women Rectors: A Case Study from Portugal, in: Kate White and Pat O'Connor (ed.), Gendered Success in Higher Education, London: Palgrave Macmillan, pp. 111-131.

Devine Patricia G., Patrick Forscher, William T.L. Cox, Anna Kaatz, Jennifer Sheridan and Molly Carnes. 2017. A Gender Bias Habit-Breaking Intervention Led to Increased Hiring of Female Faculty in STEMM Departments, "Journal of Experimental Social Psychology", 73: 211-215.

Ecklund, Elaine Howard, Lincoln Anne E. and Cassandra Tansey. 2012. Gender segregation in elite academic science, "Gender and Society", 26, 5: 693-717.

Elsevier. 2017. Gender in the Global Research Landscape, https://www.elsevier.com/_ data/ assets/pdf_file/0008/265661/ElsevierGenderReport_final_for-web.pdf [4.10.2019].

European Commission. 2009. Gender Challenge in Research Funding. Assessing the European National Scenes, Luxembourg: Office for Official Publications of the European Communities, http://ec.europa.eu/research/science-society/document_library/pdf_06/ gender-challenge-in-research-funding_en.pdf [3.06.2016].

European Commission. 2010. Flexible working time arrangements and gender equality - A comparative review of 30 European countries. Luxembourg: Publications Office of the European Union, https://publications.europa.eu/en/publication-detail/-/ publication/13a65488-9cd7-46f5-b9f4-d60e3dd09592/language-en [29.09.2019].

European Commission. 2019. She Figures 2018. Luxembourg: Publications Office of the European Union, Luxembourg, https://ec.europa.eu/info/publications/she-figures-2018_en [9.04.2019].

European Institute for Gender Equality (EIGE). 2016. Roadmap to Gender Equality Plans in Research and Higher Education Institutions. Success Factors and Common Obstacles, http://eige.europa.eu/sites/default/files/gear_roadmap_02_successfactors_obstacles_1. pdf [28.09.2016].

European Institute for Gender Equality (EIGE). n.d. Gender Bias, https:/eige.europa.eu/thesaurus/terms/1155 [19.05.2019].

Eurostat. 2019. Share of female researchers by sectors of performance, https://appsso.eurostat.ec.europa.eu/nui/show.do\# [1.10.2019].

Flick, Uwe. 2006. An Introduction to Qualitative Research, London, Thousand Oaks, CA: Sage Publications.

Götschel, Helene. 2011. Looking at High Energy Physics from a Gender Studies Perspective, https://indico.cern.ch/event/129808/attachments/89796/128553/GoetschelCERN. pdf [21.11.2017]. 
Hirshfield, Laura E. 2010. "She Won't Make Me Feel Dumb”: Identity Threat in a Male-Dominated Discipline, "International Journal of Gender, Science and Technology", 2, 1: 6-24.

Hughes, Cayce C., Kristen Schilt, Bridget K. Gorman and Jenifer L. Bratter. 2017. Framing the Faculty Gender Gap: A View from STEM Doctoral Students, "Gender, Work and Organization", 24, 4: 398-416.

Ivie, Rachel, Susan White and Raymond Y. Chu. 2016. Women's and Men's Career Choices in Astronomy and Astrophysics, "Physical Review Physics Education Research", 12, 2: 1-11.

Ivie, Rachel, Roman Czujko and Katie Stowe. 2002. Women Physicists Speak. The 2001 International Study of Women in Physics, "AIP Conference Proceedings", 628: 4-67.

Kanter, Rosabeth Moss. 1993. Men and women of the corporation, New York: Basic Books.

Lane, India F. 2007. Change in Higher Education: Understanding and Responding to Individual and Organizational Resistance, http://www.ccas.net/files/ADVANCE/Lane_Change\%20 in\%20higher\%20ed.pdf [1.05.2019].

LERU. 2018. Implicit bias in academia: A challenge to the meritocratic principle and to women's careers - And what to do about it. Advice Paper no. 23, https://www.leru.org/ files/implicit-bias-in-academia-full-paper.pdf [1.05.2019].

Lee, Lisa, Wendy Faulkner and Carme Alemany. 2010. Turning Good Policies into Good Practice: Why is it so Difficult?, "International Journal of Gender, Science and Technology", 2, 1: 90-99.

Lombardo, Emanuela and Lut Mergaert. 2013. Gender Mainstreaming and Resistance to Gender Training: A Framework for Studying Implementation, "NORA - Nordic Journal of Feminist and Gender Research", 21, 4: 296-311.

Kelan, Elisabeth K. 2007. 'I don't know why'-Accounting for the scarcity of women in ICT work, "Women's Studies International Forum", 30, 6: 499-511.

McGregor, Elizabeth and Fabiola Bazi. 2001. Gender Mainstreaming in Science and Technology. A Reference Manual for Governments and Other Stakeholders, London: Commonwealth Secretariat, https://www.academia.edu/3235703/Gender_mainstreaming_in_science_and_technology [16.06.2016].

Moss-Racusin, Corinne A., Aneta K. Molenda and Charlotte R. Cramer. 2015. Can Evidence Impact Attitudes? Public Reactions to Evidence of Gender Bias in STEM Fields, "Psychology of Women Quarterly", 39, 2: 194-209.

Pettersson, Helena. 2011. Making Masculinity in Plasma Physics: Machines, Labour and Experiments, "Science Studies", 24, 1: 47-65.

Powell, Stina, Malin Ah-King and Anita Hussénius. 2018. 'Are We to Become a Gender University?' Facets of Resistance to a Gender Equality Project, "Gender, Work and Organization", 25, 2: 127-143.

Reidl, Sybille, Ewa Krzaklewska, Lisa Schön and Marta Warat. 2019, April 30. ACT Community Mapping Report: Cooperation, Barriers and Progress in Advancing Gender Equality in Research Organisations (Version 1.0). Zenodo, http://doi.org/10.5281/zenodo.3247433 [30.09.2019].

Sekuła, Paulina and Paula Pustułka. 2016. Successful gender equality measures and conditions for improving research environment in the fields linked to physics, http://generaproject.com/dl_assets/WorkingPaper1.pdf [14.12.2017]. 
Sekuła, Paulina, Justyna Struzik, Ewa Krzaklewska and Ewelina Ciaputa. 2018. Gender Dimensions of Physics. A Qualitative Study from the European Research Area, https:// genera-project.com/portia_web/Gender_Dimensions_of_Physics.pdf [22.05.2019].

Shields, Stephanie, Matthew J. Zawadzki and Neill R. Johnson. 2011. The Impact of the Workshop Activity for Gender Equity Simulation in the Academy (W Ages-Academic) in Demonstrating Cumulative Effects of Gender Bias, "Journal of Diversity in Higher Education", 4, 2: 120-129.

Sue, Derald Wing. 2010. Microaggressions and Marginality: Manifestation, Dynamics, and Impact, Hoboken - New Jersey: John Wiley \& Sons.

Verge, Tània, Mariona Ferrer-Fons and José M. González. 2018. Resistance to Mainstreaming Gender into the Higher Education Curriculum, "European Journal of Women's Studies", 25, 1: 86-101.

Wilton, Shauna and Lynda Ross. 2017. Flexibility, Sacrifice and Insecurity: A Canadian Study Assessing the Challenges of Balancing Work and Family in Academia, "Journal of Feminist Family Therapy", 29, 1-2: 66-87.

\section{DLACZEGO TAK SIĘ DZIEJE W FIZYCE? OPINIE EUROPEJSKICH FIZYKÓW O NIERÓWNOŚCI PŁCI}

Celem artykułu jest analiza opinii i refleksji fizyków pracujących w europejskich instytucjach badawczych dotyczących przyczyn nadreprezentacji mężczyzn w tej dyscyplinie oraz barier, jakich doświadczają kobiety realizujące karierę naukową w fizyce. Artykuł opiera się na danych jakościowych pochodzących z 83 indywidualnych wywiadów pogłębionych, zebranych w latach 2016-2017 w ramach projektu „Gender Equality Network in European Research Area” (GENERA). Główne powody nierówności liczebnej kobiet i mężczyzn w fizyce, podawane w wywiadach, sytuowane są poza samymi instytucjami naukowymi - wskazuje się na proces socjalizacji dziewczynek i chłopców oraz istniejące stereotypy płciowe jako główne przyczyny nierówności. Inne powody dotyczą niedawnych przeobrażeń w obrębie akademii odnoszących się do organizacji pracy i strukturalnych uwarunkowań - wśród nich wymieniane są takie zjawiska jak prekaryzacja pracy, konkurencyjność, wymóg mobilności. Dodatkowo uczestnicy i uczestniczki badań podkreślali rolę zmaskulinizowanej kultury pracy, przyczyniającej się do występowania uprzedzeń ze względu na płeć, mikroagresji czy dyskryminacji. W nawiązaniu do niedawnych studiów pokazujących, że świadomość (nie)równości płci pozostaje istotnym elementem $\mathrm{w}$ dążeniu do implementacji strukturalnej i instytucjonalnej zmiany, artykuł wskazuje, w jaki sposób postrzeganie przez fizyków przyczyn nierówności płci może wpływać na realizację polityki równości płci w instytucjach badawczych.

Słowa kluczowe: równość płci w nauce, plany równości płci, fizyka, polityka równości płci, instytucje badawcze 